\title{
Reiner Schürmann and the Challenge of Christian Trinitarian Thought
}

\author{
JEFFERSON M. CHUA \\ ATENEO DE MANILA UNIVERSITY, PHILIPPINES
}

\begin{abstract}
Reiner Schürmann speaks of the end of Western metaphysics as the end of a mode of thinking that relies on an overriding metaphysical principle that establishes the economies that provide the space for permissible and impermissible actions. In its wake, he proposes a project of an-archy, of living without the reliance to the domination of one central metaphysical concept, but rather of kata physin, of "following the way things enter into mutual relations." Kenneth Schmitz, in reacting to Schürmann, points out that there are elements in Christian thought that can also provide new patterns of thought and action at the twilight of the end of metaphysics, namely, the notions of: (1) charity, (2) the Trinity, and (3) mystery. I shall take up the second suggestion of Schmitz and attempt to articulate what the Christian notion of the Trinity can contribute to our understanding of thought and action after the end of metaphysics. I argue that through the theological detour of Thomistic Trinitarian thought, we can chart out new patterns of thought and action, specifically on the notion of the tri-personality of the Trinity, leading to the analogical understanding of persons-as-relations. Such a consideration not only provides a sharp rebuttal to Schürmann in his understanding of "hard unity" in terms of metaphysical principles, but it also helps us understand the place of man in the contemporary world: one of charitable relationality.
\end{abstract}

Key terms Saint Thomas Aquinas, Trinity, Reiner Schürmann, Kenneth Schmitz, end of metaphysics

Budhi: A Journal of Ideas and Culture 17.2 (2013): 79-110. 
It has been said that the soul is in a certain sense all in all; for its nature directed toward universal knowledge. In this manner it is possible for the perfection of the entire world to be present in one single being.

Saint Thomas Aquinas, De Veritate

$\mathrm{T}$ There is no doubt that Martin Heidegger's pronouncement of "the end of metaphysics" has continued to animate contemporary debates in continental philosophy. These debates focus not so much on the validity of the thesis, but on how to do philosophy after this claim has come to pass. ${ }^{1}$ Reiner Schürmann belongs in this tradition of the "end of metaphysics" as he (1) expands Heidegger's project of the "history of being" by way of a powerful hermeneutic set against the whole history of Western philosophy, and (2) because he charts out the practical $^{2}$ consequences of such an acceptance of the Heideggerian thesis: the very acceptance of the closure is also an inauguration of what Schürmann calls "the age of anarchy," embodied in his call "to combat all remnants of authoritative Firsts," 3 i.e., metaphysical principles that govern thought and action.

The acceptance of the Heideggerian thesis has also led some thinkers to conceive of possibilities still unthought of, possibilities which one can only make sense of once assent has been given to the end of metaphysics. ${ }^{4}$ Kenneth Schmitz takes up Schürmann's pronouncement of the

\footnotetext{
${ }^{1}$ Mark Wrathall, "Between the Earth and Sky: Heidegger on Life After the Death of God," in Religion After Metaphysics, ed. Mark Wrathall (Cambridge: Cambridge University Press, 2003), 77.

2 I am using "practical" rather gratuitously, since Schürmann himself questions the very distinction between "practical philosophy" and "theoretical philosophy." In fact, as we will see later, Schürmann problematizes the very unity between thinking and acting, thus providing a frame for his seminal work, Heidegger on Being and Acting: From Principles to Anarchy.

${ }^{3}$ Reiner Schürmann, "What Must I Do?' At the End of Metaphysics: Ethical Norms and the Hypothesis of a Historical Closure," in Phenomenology in a Pluralistic Context, ed. William McBride and Kevin Schrag (Albany: State University of New York Press, 1983), 64.

${ }^{4}$ Jean-Luc Marion, “The End of the End of Metaphysics,” Epochē 2 (1994): 18.
} 
contemporary age as the age of anarchy, and offers the wager that this inauguration invites not only a re-evaluation of Schürmann's claims, but also reveals possibilities that could engender "new movements of thought and action." 5 He identifies three essential elements in Schürmann's understanding of the "end of metaphysics" and offers a threefold counterclaim from the purview of Christian philosophy: "To domineering power philosophy offers caring presence; to sheer unity it expands into the primordial harmony of plurality within unity; and to darkness of reductive closure it opens out onto the inexhaustible light of mystery." ${ }^{6}$ I shall take up one of his counterclaims, namely, the elucidation of the Trinity, in order to answer Schürmann's charge that metaphysical epochs are governed by their respective "First Principles." Thus, the question: does the Christian notion of the Trinity avoid the metaphysical pitfalls elaborated by Schürmann, thus opening up the possibility for a new kind of acting and thinking from the purview of Christian philosophy?

The task of this essay is to follow up on Schmitz's cue on the Trinity and see if it indeed opens up new paths of thought and action. I share in his hope that it indeed opens up these paths, and I argue that Schmitz is justified in bringing up the Christian notion of the Trinity in response to Schürmann. In order to show this, we will first chart Schürmann's expansion of Heidegger's project through his interpretation of the history of Being as a history of metaphysical firsts, culminating in Heidegger's pronouncement of the closure of the metaphysical field. From this, we shall see how Schmitz responds to Schürmann's claims by pointing out that Christian philosophy has resources that can provide a new ground of thinking and acting even after the closure of the onto-theological field. We shall take up the Christian notion of the Trinity by looking at Saint

\footnotetext{
${ }^{5}$ Kenneth Schmitz, "From Anarchy to Principles: Deconstruction and the Resources of Christian Philosophy," Council of Research and Values in Philosophy, accessed March 3, 2013, http://www.crvp.org/book/Series04/IVA-1/chapter_xvi.htm.

${ }^{6} \mathrm{Ibid}$.
} 
Thomas Aquinas, specifically his notion of subsistent relations. This detour will help us appreciate Schmitz's claim that contra Schürmann, the Trinity can serve as a principle of unity that is not reducible to a hard unity, but rather, "a unity charged with abundance." Seen in a new light, we can then say that the resources of Christian philosophy offer a new way of responding to the charge against metaphysics, but only after the closure of the metaphysical field. This paper hopes to chart new possibilities for thinking and acting from the point of view of Christian philosophy in this age of anarchy.

\section{Heidegger-Schürmann and the Deconstruction of the Practical}

Schürmann takes off from Heidegger's conviction that metaphysics, in all its various forms across history, has finally come to its "end." This end cannot mean the completion of a previous teleological unity, but rather an opening of a possibility of an "other thinking." Such an end signifies not only the end of traditional metaphysical thinking and discourse, but also the radical questioning of all dimensions of human life and becoming. Schürmann traces-with Heidegger-three essential elements in metaphysical thinking that has dominated philosophical thinking throughout history, culminating in Nietzsche's pronouncement on the "history of an error:" (1) the archeological—in the sense of being grounded in an arche-nature of metaphysical thinking that have defined epochs across history; (2) the pros hen [in relation to one] relationality that establishes the economical order of things in their respective historicometaphysical epochs; and finally, (3) what Schürmann calls "the hypothesis of closure." These three elements, taken together, constitute the closure of the metaphysical field, and with it, the inauguration of what he calls the "age of anarchy," where one is enjoined to appropriate a disposition of

\footnotetext{
${ }^{7}$ Martin Heidegger, "The End of Philosophy and the Task of Thinking," in On Time and Being, trans. Joan Stambaugh (New York: Harper and Row, Inc., 1972), 57.
} 
kata physin (following the way things enter into mutual relations), ${ }^{8}$ following the "sole movement of coming-to-presence of phyein." $\mathrm{It}$ is in the elaboration of the closure of metaphysical thinking that the previously held grounds for human action become problematized to the point of disintegration. What is thus at stake in Schürmann's deconstruction of metaphysics is nothing less than the fragmentation of human discourse and the dislocation of human action from its metaphysical roots-hence, the unity between metaphysics and ethics.

On the archeological nature of metaphysics, we see that Schürmann, in his attempt to follow the Heideggerian critique of metaphysics, also uncovers an underlying structure in metaphysical thinking: the double sense of archè as both beginning and rule. ${ }^{10}$ Metaphysical epochsmanifested as historical epochs - then have a characteristic of grounding that establishes itself as (1) the founding principle of an epoch, or in this case, the defining Zeitgeist of a particular epoch; and (2) the machination of power for the perpetuation of that Zeitgeist. He shows us the grounding character of a particular metaphysical epoch, and how this grounding "assigns a place" for actions-manifested in culture and the human sciences-determining their possibility (or impossibility). We thus see in this analysis how thinking is conditioned by the metaphysical epoch one is in, and that this metaphysical thinking is itself constitutive of the aletheiological constructions of human thinking - in other words, the es gibt structures the constellation of human thinking and doing. Such an establishment of an epoch, we can say, is dependent upon how people understand Being (and hence the relations of things to each other) as it is revealed in its own historical particularity. It is the instance-others would speak of an event—of unconcealment in which an economy is established.

\footnotetext{
${ }^{8}$ This is Schürmann's translation of the Greek phrase. The more literal translation of this phrase would be "according to nature." See Schürmann, "What Must I Do," 63.

9 Schürmann, "What Must I Do," 63.

${ }^{10}$ Schürmann, Heidegger on Being and Acting, 30.
} 
We can then say that historico-metaphysical epochs are defined according to their archeological foundations, and patterns of thought and action reflect these epochs, ${ }^{11}$ even if these patterns are discernible only after such epochs have come and gone. ${ }^{12}$

This leads us to the second dimension in Schürmann's deconstruction: the varieties of human discourses draw their rationale from an overriding metaphysical principle. ${ }^{13}$ The many-to-the-one structure traces its origins to Aristotle, whom Schürmann assigns a foundational place in Western philosophical thinking:

The categories for understanding the body politic were derived from the analysis of sensible bodies and were transposed into practical discourse from speculative or 'ontological' discourse. Aristotle's Physics, the Grundbuch, 'foundational book,' of Western philosophy, provided practical philosophy with its elementary vocabulary worked out in the context of movement and its causes. . . What does practical philosophy inherit from its father, speculative philosophy? Precisely the reference to a first. In order that there be knowledge of the sensible there must be a first to which the multiple can be referred and thus be made true and verified. ${ }^{14}$

Aristotle's construction of the causal relations that offer intelligibility to beings thus becomes the defining metaphysical relation that renders intelligible the basic metaphysical paradox of the One and the Many. Schürmann

${ }^{11}$ Ibid., 35 .

12 To be sure, Schürmann gives a more in-depth analysis of this phenomenon; he also speaks of how such epochs only "come to the mind" only after its decline, that is, only after the epoch has withered away, precisely because it is already thinkable that it is not the present state of affairs anymore. For if it were the present state of affairs, it will absolutely be unthinkable that it becomes a mere "stage" or "era" across history; indeed, because of its archeological dimension. But this will not be elaborated to the extent that Schürmann does for the sake of the argument.

${ }^{13}$ Schürmann, "What Must I Do," 53.

${ }^{14}$ Schürmann, Heidegger on Being and Acting, 39. 
further adds that such an economic establishment also assigns a sense of direction or teleology to beings, in reference to the defining One in its historical particularity. ${ }^{15}$, What we have in the archeological establishment of an epoch by virtue of the aletheiological construction of thought, then, is an economy that assigns a relationality of the plurality of beings to a central, overriding, and unifying principle. This relationality is the metaphysical structure of origin-purpose in the causal language of the pros ben relation. This further explains why some actions are discernible only in their respective epochs, because it would not make sense for us now why the Moderns, for example, would insist on the objectivity of our sensible experiences: precisely because everything is assigned a relation to an overriding principle-which we now know to be the Cogito, or the subject-peculiar to modernity. Thus, on this point we can rightly speak of a metaphysical construction of historical era-it is the overriding assignment of a principle that makes for a historico-metaphysical epoch.

Such metaphysical constructions, however, are not immortal. This leads us to our final point, following Schürmann: the closure of the metaphysical field also initiates the eventual disintegration of the pros hen rationality ${ }^{16} \mathrm{He}$ traces the gradual unviability of the metaphysical relation of pros hen in Heidegger: "'the truth of the coming to presence of being' designates nothing more and nothing less than the withering away of epochal principles; a modality of presence such that the 'fable' of the ideal worldHeidegger's notion of the epoche- -is no longer necessary to give it coherence and cohesion. The 'truth,' aletheia, of being designates the utterly contingent flux of interchange among things, without the governance of a metaphysical First."17 With Schürmann, through Heidegger, we see (1) the closure of the onto-theological metaphysical field in the articulation of the dual (and simultaneous) presencing of Being as both concealed and

\footnotetext{
15 Ibid.

${ }^{16}$ Ibid., 38.

${ }^{17}$ Schürmann, "What Must I Do," 56.
} 
unconcealed; and more importantly (2) the possibility of defining an epochal history because a closure has been inaugurated, allowing one to think of the traces of these metaphysical first principles across history. Schürmann interprets the Heideggerian turn as: "The hypothesis of closure [that] also confers its radicality on the deconstructionist move: action bereft of arche is thinkable only at the moment when the problematic of 'being'-inherited from the closed field of metaphysics but subjected on its threshold to a transmutation, to a passover-emerges from ontologies that dismisses them."18 What comes to light, therefore, at the turning of thinking, is the very possibility of action without its reliance on the old totalizing system of the pros hen relationality.

For Schürmann, a comprehensive and synthetic construction of an ethical theory—-the dream of practical philosophy—is no longer possible after the closure of the metaphysical field. This sets up for us what Schürmann calls "the age of anarchy." To be sure, he is not at all denying the possibility of meaningful action after metaphysics has imploded; he is claiming, rather, that meaningful action can no longer rely on an implicit metaphysical order of relationality. Meaning, then, is to be found elsewhere-to locate it in human flourishing is to revert back to the pros ben relation. What then "grounds" human action, if it is not to be grounded in human beings?

He speaks of "following the way things enter into mutual relations," a certain kata physin — of moving (in this case, acting) according to the coming-to-presence of things in relation to one another. He echoes Heidegger's insistence on the nature of this thinking and acting as a response to the mutual relations of what Heidegger calls the Fourfold: "if thinking is essentially a response, an echo, a reverberation of appearing as such, then it can hardly be initiating, taking initiatives."19 This response thus cannot initiate anything from its own power, because all foundations

\footnotetext{
18 Ibid., 57.

${ }^{19}$ Schürmann, Heidegger on Being and Acting, 124.
} 
concerning the power of human beings to initiate action have been destabilized, revealing a primordial reception from the es Gibt, which precedes any calculative effort to explain this "debt." The response is, therefore, an active waiting for "a possibility whose contour remains obscure, whose coming remains uncertain." ${ }^{20}$ Schürmann concludes:

What must I do at the end of metaphysics? Combat all remnants of authoritative Firsts. . . As an immobilization of the flux of phyein, the formation of the moral law constitutes, here most evidently, its own transgression: a transgression towards that full sense of physis that Aristotle discarded for the sake of a "first philosophy" entirely guided by the representation of ends; a transgression, in other words, towards a mode of acting purely "according to anarchic presence," kata physin. ${ }^{21}$

The closure of the metaphysical field therefore also produces the closure of any inquiry into the "good life" grounded in rational foundations. For Schürmann, the end of metaphysics can only mean an end of a humanism grounded in ethico-rational inquiry: the age of anarchy.

\section{Opening up the Question of Hard Unity}

In raising the issue regarding the end of metaphysics, questions hitherto unthinkable because of their respective economies of presence have now surfaced. Both Schürmann and Heidegger articulate the elements of metaphysical thinking that have now fallen into disrepute, and in pointing out these problematic assumptions of traditional metaphysics, liberate philosophical inquiry from the baggage of these past economies. One of these questions concerns itself with religion. Schmitz points out that "the

\footnotetext{
${ }^{20}$ Heidegger, "End of Philosophy," 60.

${ }^{21}$ Schürmann, "What Must I Do," 64.
} 
most perennial of the traditional views is one that draws its support from both Biblical religion and from what may be called Christian philosophy."22 Christianity's narrative of origins-creatio ex nibilo-provides fodder for Schürmann and Heidegger to attack and brand Christian-inspired metaphysics as onto-theological. Furthermore, the Nietzschean thesis of the "death of god" seems to corroborate the Heideggerian (and Schürmann's) claim that any fixed point of reference-in this case, Godhas become untenable, since it has been shown that all metaphysics is in fact merely modes of fabulation. ${ }^{23}$ It then becomes clear why religion (in this case, Christianity), among other social phenomena, assumes such a questionable state in our time: it establishes a First that has, in the course of the development of this idea in history, acquired the flavor of metaphysical thinking. It may seem like Christian thought-if we follow Schürmann-still has not questioned its own totalizing foundations. The question, therefore, regards the hard unity of the metaphysical principles that Schürmann points out: Does the inauguration of the age of anarchy also mean the eventual demise of Christianity, insofar as Christianity seems to ground itself in a particular metaphysical system?

Being mindful of the rather precarious position that religious belief and religion in general find themselves in at the dawn of Schürmann's deconstruction, Kenneth Schmitz presents a counterproposal:

At each of these pressure points there is a Christian disclosure that invites appropriation and interpretation by a Christian philosophy. Let me take up each of the three most important charges. They are: first, the inseparability of domination from inception; second, the reduction of all things within the cosmos, ordo, or system to a uniform principle; and third, the subjugation of thought and action to the

\footnotetext{
22 Schmitz, "From Anarchy to Principles."

${ }^{23}$ Wrathall, "Between the Earth and Sky," 71.
} 
closure brought about by the origin. Each of these pressurepoints invites us to reexamine our own understanding of origin in the light of Christian philosophy. ${ }^{24}$

He further elaborates on these points and juxtaposes three moments in the disclosure of Christian revelation that invite a rethinking of categories - perhaps, a new conception of metaphysics: "To domination, a Christian philosophy offers: giving; to hard unity: a unity charged with abundance; and to hiddenness: the mystery of presence." 25 What motivates Schmitz to undertake this project?

The inauguration of the end of metaphysics is not merely an abandonment of an "old thinking" into a new one, but is also a reorientation of thought. This is now possible for the simple fact that the "end of metaphysics" thesis has charted out the pitfalls of closing oneself up to a particular mode of calculative thinking. Insofar as Christian thought is concerned, this only amounts to a retrieval within the tradition with these markers pointed out by Schürmann in mind. Taking up one of these disclosures, then, might offer us new patterns of understanding human life and flourishing, as Schmitz so rightly claims. As the demands for providing a sustained analysis of all of Schmitz's proposals exceeds the confines of this essay, I shall be taking up one of his claims, namely, the Christian disclosure of the Trinity and the invitation to rethink the category of relational domination-that is, the pros ben schema-elaborated by Schürmann.

\section{On Abundant Unity: Saint Thomas and the Trinity}

Schmitz responds to Schürmann's elaboration of the domination of the pros ben relation and invites his readers to rethink this metaphysical structure in light of the Christian disclosure of the doctrine of the Trinity:

\footnotetext{
${ }^{24}$ Schmitz, "From Anarchy to Principles."

25 Ibid.
} 
There stands a Christian disclosure that should give a Christian philosopher pause; for in the struggle to move within a belief in one God, the early Christians arrived at the notion - not of Tritheism, three gods-but of the Trinity, and the Tri-unity of the Godhead. Anyone who has followed the Fathers and the Councils on this matter realizes with what difficulty a new and richer sense of unity had to be forged: to retain the unity and simplicity of God, while enriching the unity and simplicity with a "plurification" that arose from the very abundance of the divine life. ${ }^{26}$

He then says that such a rethinking has "not yet been cultivated in philosophy to the degree that it needed." 27 To be sure, there has been a resurgence of the philosophical study of the Christian notion of the Trinity, which was once considered a topic reserved only for systematic theologians. ${ }^{28}$ But the problematic has yet to be thought of extensively in the context of the closure of metaphysical inquiry. Furthermore, these questions tend to reduce the whole issue into a system of calculative logic. Even if Moreland and Craig advocate a kind of Trinity monotheism that provides a coherent - that is to say, logical and sound - understanding of "three persons in one substance," I am doubtful that such elaborations on the Trinity take the "postmodern" phenomenon seriously enough, as it is clear that such formulations must confront the reality that the end of metaphysics has rendered the questions of Moreland and Craig suspect. Even some theologians lament the preoccupation of Trinitarian theology with mere puzzle-solving, so much so that the most fundamental "problems and paradoxes" with comparative Trinitarian theologies must "be thought of afresh." ${ }^{29}$ I share in Schmitz's view that Schürmann and

\footnotetext{
${ }^{26}$ Schmitz, "From Anarchy to Principles."

27 Ibid.

${ }^{28}$ J. P. Moreland and William Lane Craig, "The Trinity," in Oxford Readings in Philosophical Theology, vol. 1, Trinity, Incarnation, Atonement, ed. Michael Rea (Oxford: Oxford University Press,

${ }^{29}$ Richard Cross, "Two Models of the Trinity?" in Oxford Readings in Philosophical Theology, vol. 1, Incarnation, Trinity, Atonement, ed. Michael Rea (Oxford: Oxford University Press, 2009), 126.
} 2009), 21. 
Heidegger, though it is not their intention, enjoin us to awake from our socalled dogmatic slumber. We thus echo Henri de Lubac's confidence in the novelty of the revelation of the Trinity:

If, even without philosophical training, we can resist those who tell us that matter is the ground of all being, and if we spontaneously go beyond the overly abstract views of those who tell us that spirit, or the "one," is the ground of being, it is because this mystery of the Trinity has opened up before us an entirely new perspective: the ground of all being is communion. ${ }^{30}$

As a response to Schürmann's Heideggerian pronouncement of our age of anarchy, can the Trinity provide a new insight in our attempt not only to (1) rehabilitate our own "understanding" of God, but more so (2) to address the question: What must I do at the end of metaphysics?

It is this twofold concern that will guide us in elaborating an account of the Trinity at the end of metaphysics in the thought of Saint Thomas Aquinas. Along with contemporary interpreters of Thomas, we can formulate an account of the Trinity that answers the charge of SchürmannHeidegger, not for the sake of refuting them, but more for the sake of restating the profound depth of Thomistic Trinitarian thought freed from the uncritical determinations of onto-theological philosophy. In this restatement, novel patterns of human thought and action may be discerned, advancing Schmitz's conviction that such restatements are necessary because, as Heidegger himself would lament, our language has suffered enough hegemony from metaphysical thought, ${ }^{31}$ and that the pronouncement of the closure enjoins us to think beyond-not withoutthese metaphysical determinations. But first it must be established: Was Saint Thomas an onto-theological thinker?

\footnotetext{
${ }^{30}$ Henri de Lubac, S.J., The Christian Faith: An Essay on the Structure of the Apostles' Creed, trans. Richard Arnandez, F.S.C. (San Francisco: Ignatius Press, 1986), 13.

31 Martin Heidegger, "The Onto-Theo-Logical Constitution of Metaphysics," in Identity and Difference, trans. Joan Stambaugh (Chicago: University of Chicago Press, 2002), 74.
} 
Surely such a charge could not have been evaded, given his own indebtedness to Aristotle, not to mention his use of the metaphysical lexicon in explaining his points. Deeper still, some people have thought that his treatment of God-especially with the divine names-pulls him to the abyss of onto-theology. The early Marion represented one of the more forceful criticisms of Saint Thomas in God Without Being: "the divine certainly did not await Thomas to enter into metaphysics; but it is only with Saint Thomas that the God revealed in Jesus Christ under the name of charity finds himself summoned under the role of the divine in metaphysics, in assuming esse/ens as his proper name." 32 It is then not surprising that Heidegger (and to this extent Schürmann) glosses over the entire medieval tradition - there was no need to elaborate on their thought since it was through and through metaphysical (despite clear textual evidence pointing otherwise). ${ }^{33}$ Certainly there are reasons that warrant this suspicion towards St Thomas. This necessitates us to establish, even if only in broad strokes, that Saint Thomas was not an onto-theological thinker.

We can focus on two essential elements of Saint Thomas's thought that allow us to appreciate him well outside the determinations of calculative metaphysical thought: (1) his conception of the horizon of human reason as reaching towards God (hence, his conception of "metaphysics"), and (2) the priority of the movement of faith-which is a response to revelationover any approximate knowledge of God.

On the first point, we see that for Saint Thomas, human reason, at its best, can only apprehend the effects of God, and has no direct access to the full knowledge of God: "Using natural reason, man can know God only from creatures." 34 Such a philosophical attempt at trying to understand God, Gilles Emery writes, can only know the essential

\footnotetext{
32 Marion, God Without Being: Hors-Texte, 2nd ed., trans. Thomas Carlson (Chicago: University of Chicago Press, 2012), 82.

${ }^{33}$ Peperzak, "Religion After Onto-Theology?" in Religion After Metaphysics, ed. Mark A. Taylor (Cambridge: Cambridge University Press, 2003), 107.

${ }^{34}$ Saint Thomas Aquinas, Summa Theologiae, Ia, q. 32, a. 1. I use Emery's quotations in his book, which he obtains from the Blackfriars English translation. See Saint Thomas Aquinas, Summa Theologiae, Blackfriars English Translation, 60 vols. (London and New York, 1964-1976).
} 
attributes of God-illumined through reason-but "no more than that."35 Hence, one can say that for Thomas, there can be no possible demonstrable proof of the necessity of believing in God-any attempt at "knowing" God solely based on human reason and volition amounts to idolatry. Though it is true that philosophical reason can provide cogent arguments for God's existence, it cannot and should not provide the sole ground for believing in God. ${ }^{36}$ At the heart of this distinction between philosophical demonstration and revelatory faith is his conception of the Creator-creature distinction: "God as such does not belong to metaphysics, or to theology, or to ens commune, or to ens in quantum ens." 37 God remains the principle of the "objects" of metaphysical inquiry, inasmuch as the subject matter of metaphysics is being. He stands outside metaphysics precisely because he is the ground on which all metaphysics rests. Thomas is thus actually doing metaphysics-as metaphysics is described by Schürmann and Heidegger-but metaphysics insofar as God is not included within the fold of the investigation. God remains the principle of things, but God cannot occupy Schürmann's "metaphysical First” simply because God, for Thomas, lies outside things: "God, in order to distance himself from this [things], will have to make himself known as incomprehensible."38

What place does God occupy, then, if metaphysical thinking cannot circumscribe Him? This leads us to our second point: "Only the "truth of faith,' to the exclusion of any other reason, leads us to acknowledge God's tri-personality." 39 It is only through the primacy of revelation that we are led towards a contemplation of God. Philosophical reason can only do so much in showing how belief is intelligible, but it cannot in any way claim to

35 Gilles Emery, O.P., The Trinitarian Theology of St. Thomas Aquinas, trans. Francesca Aran Murphy (Oxford: Oxford University Press, 2007), 23.

${ }_{36}$ W. Norris Clarke, S.J., The One and the Many: a Contemporary Thomistic Metaphysics (Indiana: University of Notre Dame Press, 2001), 214.

${ }^{37}$ Marion, God Without Being, 208.

38 Ibid., 214.

${ }^{39}$ Emery, Trinitarian Theology, 25. 
demonstrate that there is a God, because God is incomprehensible, if we take comprehension to be a total grasp of a concept. More originary than man's rational capacity is the light of the Word that illuminates all that is. ${ }^{40}$ Indeed, Saint Thomas believes that intellect is illuminated by grace, and it is this illumination that allows one to receive revelation as a mystery.

Human reason alone cannot gain access to God-it is God's selfcommunication that allows the human intellect to have some measure of understanding of the truth of God. It is the relational structure of this divine self-communication that also allows for the intelligibility of other beings; beings become intelligible insofar as God creates these beings, i.e., insofar as beings are thought in the Infinite mind. ${ }^{41}$ To realize this distance is to initiate the contemplative act. Because distance allows for the communicability of revelation, to think about God without reducing God to the objectivity of concepts is itself a spiritual exercise.

Saint Thomas stands outside calculative metaphysics since he was using an entirely different mode of discourse when he talked about God using metaphysical language, and not at all the mode of discourse that Heidegger refers to as the "onto-theo-logic." Saint Thomas wanted to show that belief in God made sense, but that this sense is aided and completed by something beyond the realm of human reason, which is revelation. ${ }^{42} \mathrm{We}$ can thus say that Thomas balances between the essential finitude of human intellect, and how this finitude is infinitely transgressed by revelation.

Given these presuppositions in Thomas's method, we are now more or less able to understand what Thomas says about the Triune God. It must be noted here, however, that the following exposition is a theological detour made in order to elaborate on a philosophical point. Philosophy cannot admit to the historicality of a theological claim, and at its best, as Marion

\footnotetext{
${ }^{40}$ Clarke, One and the Many, 296.

41 Ibid.

${ }^{42}$ Emery, Trinitarian Theology, 35.
} 
emphasizes, it can only admit to its possibility. ${ }^{43}$ The forthcoming section, therefore, is explicitly theological in character; it would later be appropriated philosophically as we respond to Schürmann's challenge. With this methodological caveat, we can now proceed to a discussion of the Triune God.

\section{The Trinitarian Thought of Saint Thomas: Person and Relation}

For Saint Thomas, "knowledge" of the Trinity is only possible because of the fact that it was - and continues to be-revealed: "The plurality of persons in God is an article of faith, and natural reason is unable to discuss and adequately understand it though we hope to understand it in heaven when we shall see God in his essence, and faith will be succeeded by vision." 44 It is through faith that we come to a contemplative relation to the Trinity. But despite this ultimate incomprehensibility, it is nonetheless intelligible by virtue of one's reception of revelation through faith. An essential link that mediates this seemingly unbridgeable gulf between God and human reason is Thomas's conviction that reason cannot contradict revealed truth. This "intelligibility of faith" is only possible because it was revealed as communicable. ${ }^{45}$ Thomas continues: "it is useful for the human reason to exercise itself in such arguments however weak they may be, provided that there is no presumption to comprehend or to demonstrate. For to be able to see

${ }^{43}$ Jean-Luc Marion, "The Possible and Revelation," in The Visible and the Revealed, trans. Christina M. Gewandtner (New York: Fordham University Press, 2008), 11. "What we are doing is methodological in character; the theological claim can, at its best, only articulate its historical embeddedness, and it gives philosophy the necessary resources in order for it to be intelligible without admitting to the very same historicality that a theological claim makes, i.e., God was the Logos incarnate in Jesus." See also Jean-Luc Marion, "Christian Philosophy: Hermeneutic or Heuristic?" in The Question of Christian Philosophy Today, ed. Francis J. Ambrosio (New York: Fordham University Press, 1999), 263.

${ }_{44}$ Saint Thomas Aquinas, Quaestiones Disputatae de Potentia Dei, trans. the English Dominican Fathers (Westminster, Maryland: the Newman Press, 1952), q. 9, a. 5.

${ }^{45}$ Emery, Trinitarian Theology, 29. It must also be emphasized here that Thomas had in mind the heresies that hounded the Christian faith during their time, thus acquiring the need for its intelligibility by virtue of its use of philosophical reason, which was the dominant form of discourse on God during their time. 
something of the loftiest realities, however thin and weak the sight may be is . . a cause of the greatest joy." 46 From these passages, one can infer that for Thomas, it was impossible to philosophically elucidate the Trinity in a comprehensively rational manner, since the Trinity is an object of revelation-thus not of human agency-and moreover is revealed as a mystery. This mystery constitutes the whole drama of the Christian salvation history, a history that has attempted (and fails most of the time) to interpret this revealed truth.

The revelation of the Trinity also reveals the implicit structure-we can say meaning - of reality: the procession of the Trinitarian PersonsFather, Son, Holy Spirit—reflects the movement of God in the world, that all created beings participate in the movement of God himself. ${ }^{47}$ It is through this revelation that we can discern the structure and sense of reality: what is at stake is nothing less than the intelligibility of reality itself. Articulating this revelation —and hence, the structure of reality-gives us the tools with which to confront Schürmann's challenge at the end of metaphysics: Trinitarian thought provides a different paradigm from the totalizing tendency of the pros ben schema, and yet this Trinitarian thinking does not do away with the sense and purpose of reality. We then understand why Schmitz so emphasized the importance of the Trinity in rearticulating "new paths of thought and action:" it amounted to thinking and doing that mirrored the underlying structure of reality, made visible by the Triune God in full freedom. ${ }^{48}$

Central to this revelation is the self-manifestation and selfcommunication of God in the person of Jesus Christ. Indeed, one cannot consider oneself Christian if one rejects fundamental article of faith: the mystery of the incarnation, death, and resurrection of Christ. It is this irruption in history that also inaugurates the saturated revelation of the Trinity: the very revelation that God is not One, but "Three persons in one

${ }^{46}$ Saint Thomas Aquinas, Summa Contra Gentiles, trans. Anton C. Pegis (Indiana: University of Notre Dame Press, 1975), bk. I, ch. 8.

${ }^{47}$ Emery, Trinitarian Theology, 40.

${ }^{48}$ Emery, Trinitarian Theology, 42. 
nature," a revelation given in God's full freedom and charity. ${ }^{49}$ It is this active presencing of God that constitutes the structure of revelation: one of action that is "directly concerned with man." 50 In fact, one can see that it is the revelation of God as person(s)_-Father, Son, and Spirit - that will reveal the profound sense of the Trinity and how the Christian Trinitarian discourse answers to Schürmann's claims against metaphysics and about the state of the contemporary age. It is in Saint Thomas that we get one of the more comprehensive accounts of the persons of God, and analogically, our own personhood. It is in the emphasis on the persons of God that will confront Schürmann-Heidegger with a different stake at the structure of reality and of human acting and doing: one of plurality in unity. It is quite challenging to present a single and isolated view of Thomas's conception of the person, since his treatment of the person is too vast and comprehensive. It should suffice for the purposes of this essay to focus on his conception of the person within the discourse on the Trinity. It is here that we see the key insight into Saint Thomas's conception of the Trinity.

Central in understanding Saint Thomas's Trinitarian thought is the status of the person as relation. ${ }^{51}$ In Saint Thomas's definition of person, "the terms 'individual substance' is used to mean a singular being in the category of substance; 'rational nature' is added to mean the singular being among rational substances." 52 Such a "rational nature" of man speaks of its mode of existence, that is to say, "having complete purchase on the exercise of its own act of existence." 53 In other words, the person for Saint Thomas is an individual substance (a concrete and definite substance) that has the capability to act. This can be seen not only with the person but, for Saint Thomas, also in other beings, by virtue of their self-communicability,

${ }^{49}$ W. Norris Clarke, S.J., "To Be is to be Substance-in-Relation," in Explorations in Metaphysics (Notre Dame: University of Notre Dame Press, 1994), 108.

${ }^{50}$ De Lubac, Christian Faith, 88.

${ }^{51}$ Emery, Trinitarian Theology, 102.

52 Saint Thomas, Summa Theologiae, Ia, q. 29, a. 1.

${ }^{53}$ Emery, Trinitarian Theology, 105. 
i.e., trueness: beings act in the most real sense, only varying in degrees according to their modes of existence. ${ }^{54}$ What sets the person apart from all other beings is, for Saint Thomas, our "rational nature," that is to say, our active and conscious construction of these relations with and for other beings. It is in this sense that human persons are relations: human persons, in their mode of existence as rational beings, enter into relations because they choose to be in relations, i.e., actively by virtue of the rational nature of the person. It is in this self-manifestation and self-communicability, Clarke concludes, that beings are substances-in-relation. ${ }^{55}$

But in the Trinity, we find that "person" is understood as threefold in one substance. This presents problems, especially in light of more common ways of understanding relations, i.e., the Aristotelian notion of the accidental relation. If the relations between persons are merely accidental, then we would have added something external to these substances, which would be contrary to the nature of God to have "everything that He has," as elaborated by Augustine. ${ }^{56}$ How then can we present the distinction between the persons in the Trinitarian economy without assenting to the accidental nature of relations? Furthermore, how can we distinguish the relations found in the Trinitarian economy from relations among beings?

Saint Thomas proposes a solution to these problems in his conception of "subsistent relations." Emery writes: "We have already seen that, as far as its proper notion or ratio is concerned, relations consists in a pure reference to another (a connection of origin) but in its own being it is purely and simply identical with the existence of the divine essence. This is worked out in such a way that, in God, the principle of distinction (and relation) is no different from the reality thus distinguished (the person)." ${ }^{57}$

${ }^{54}$ Clarke, "Substance-in-Relation," 107.

${ }^{55}$ Clarke, Substance-in-Relation, 113.

${ }^{56}$ Gerald O' Collins, S.J., The Tripersonal God: Understanding and Interpreting the Trinity (New York: Paulist Press, 1999), 145.

${ }^{57}$ Emery, Trinitarian Theology, 117. 
The relation between the Divine persons also constitutes what we say when we speak of God-they are not "outside" the persons of God, because the relations themselves are at the heart of the substantiality of these persons. Clarke also echoes the same view of this constitution as substance-in-relations: "a related is not identical with the relation which makes it related, but neither is it separable from it." 58 Thus, one can say that for Thomas, person and relation are inseparable.

One should be cautious, however, in thinking that subsistent relations are identical with substance-as-relations. Rather, they share an analogical relationship with respect to their relations. Subsistent relations are different from substance-as-relations due to the fact that the subsistent relations share in the one Divine essence, with the principle of distinction being the relations. ${ }^{59}$ Whereas for substance-as-relations, the persons involved are individuated rational substances. What remains similar between them is the existence of these relations: the relations between human persons and the relations between the Divine Persons are real. ${ }^{60} \mathrm{It}$ is in this similarity and difference, grounded on the causal relation between Creator and creatures, that subsistent relations and substance-as-relations are analogically related in the Thomistic sense:

If now there be an agent outside even genus, its effects will bear an even remoter resemblance to the agent. The likeness borne will not now be of the same specific or generic type as the form of the agent but will present the sort of analogy that holds between all things because they have existence in common. ${ }^{61}$

One must remember that the knowledge of the Trinitarian relations are as far as the human intellect can go to approximate the nature of the Divine, as it cannot access its innate nature. Though substance as relations

\footnotetext{
${ }^{58}$ Clarke, Substance-in-Relation, 109.

${ }^{59}$ Saint Thomas, Summa Theologiae, Ia, q. 32, a. 1.

${ }^{60}$ Ibid., Ia, q. 28, a. 1.

${ }^{61}$ Ibid., Ia, q. 4, a. 3.
} 
can be demonstrated philosophically, the Trinitarian subsistent relations are wholly revelatory, and are only known through human reason indirectly, i.e., through the experience of created beings. "Persons" in the Trinity are ontologically different from that of human "persons," as the Trinitarian Persons are complete-in the sense of sharing the same Divine Essence, thus not having any extrinsic cause-as opposed human persons (and other beings for that matter) who are by nature "accidental" in view of their creator. ${ }^{62}$ Despite this radical difference, a likeness remains insofar as the philosophical demonstration can also be employed in explaining the Trinitarian relations, while maintaining the necessary distance from it, i.e., not being identical. The fundamental difference concerns itself with the identity of the Divine Substance that is shared in the Persons of the Trinity: "in God relation and nature [essence] are existentially not two things but one and the same." 63 God's subsistent relations is different from substance-as-relations due to the fact that "substance-as-relations" refers to the relational nature of distinct substances interacting with one another, whereas for God, there is one Divine Essence in the three Persons, and this can only be intelligible if essence is the same with relations.

It is here that we see the radical nature of Saint Thomas's Trinitarian thought: by pointing out that substance-as-relations between persons shares an analogical relationship to the subsistent relations between Persons in the Trinity, we are able to take the theory of subsistent relations as an exemplar of reality, insofar as our insight into persons as substancein-relations are incomplete without the creative act of the tri-Personal God. The Trinity, the subsistent relations of the Three Divine Personsrevealed to us in the form of the incarnate Person, the Son-reveals to us the nature of "relationship" and serves as its model. Further, because of the theory of subsistent relations, we see that it is possible to believe in a tri-Personal God: the relations constitute the tri-Personality of God, and

\footnotetext{
62 Ibid., Ia, q. 28, a. 2.

63 Ibid.
} 
these relations are analogical to how human persons build and sustain their relations with other beings. This is the key insight of Saint Thomas's exposition on relations.

Because the relations constitute the tri-personality of God, we can thus consider that God, in this case, is not merely One, if we take "one" to be a solitary origin both of power and inception: it is the Trinitarian relations between persons that make up the Oneness of God. De Lubac sums it up perfectly: "God is one, and none of the three Divine Persons can be conceived, in Himself or His operations, as separate from the other two." 64 To think of the Christian God, then, amounts to contemplating the relational structure that sustains the tri-personality of God. But it is in the attempt at contemplating the Trinitarian movement of God that a further truth is revealed: the fundamental belief that all of creation is made in the image and likeness of God also means that all of creation somehow shares this relationality with fellow beings (analogically), especially human persons, who are endowed with intellect and consciousness. ${ }^{65}$ The inner structure of the relationality of God reflects His creation as turning toward unity-universum - that is, in relations. This substantial relationality is seen best with the human person, whose form Jesus also assumes, where the human person in his or her special place in the hierarchy of Being (for Saint Thomas) has the unique capability for interiority, which is to say our spiritual constitution, which Clarke identifies to be our intellect and will taken together. ${ }^{66}$ The human person, in his or her hopes and dreams, failures and successes, becomes the perennial image of God, by virtue of his or her substance-in-relation, which he or she cannot but act on, since substantiality "exists for the sake of its operations." ${ }^{\circ 7}$ It is in the constitutionality of substance-in-relation that love is possible: "To be

${ }^{64}$ De Lubac, Christian Faith, 126.

${ }^{65}$ Clarke, "Substance-in-Relation," 109.

${ }^{66}$ W. Norris Clarke, S.J., "The Self as Source of Meaning in Metaphysics," The Review of Metaphysics 21, no. 4 (1968): 611.

${ }^{67}$ Saint Thomas, Summa Contra Gentiles, bk. III, ch. 26. 
authentically for a human person is to live in love, to express itself by loving, in the broadest sense of the term, to make itself the center of the widest possible web of relationships to all things, and especially to all persons, through our two major self-relating and self-transcending powers, knowledge and love. To live as a person is to live in relation."68 The substantiality of the person thus rests on his or her relatedness to other beings, and this relatedness constitutes the activity of the person, which is exemplified in charity.

Thus, we reach the apex of the radical novelty of God's revelation: it is the truth that the human person in his relationality is called to love just as God continually loves, exemplified in the sending of His Son. ${ }^{69}$ The metaphysical expositions thus come after the event-proper of revelationthe conceptual categorization is thus secondary to the revelatory experience. We can thus make a sharp distinction between the revelation of God through the Son-self-communication par excellence-and the attempt at understanding such an event, which always exceeds thought. This means that the Thomistic metaphysical system is also a revealed truth, insofar as the "truth" is revealed and therefore is beyond the totalizing tendency of human intellect. We can then understand why for Saint Thomas, it was so important to explicitly acknowledge that philosophical reason can do no more than to approximate the "objects of faith," but primacy still rests on the event-proper of revelation. We can thus also understand why, for Saint Thomas, metaphysics was not a "science of concepts," but more of a science of judgment, which is context-specific. ${ }^{70}$ That is to say, metaphysics stands as a comprehensive and determinate system of judgments in reality, and if we are to factor in revelation as irrupting in history, we can then say that metaphysics stands as a discourse about man's receptivity to revelation.

${ }^{68}$ Clarke, "Substance-in-Relation," 117.

${ }^{69}$ To be sure, I am speaking here of the Trinitarian missions.

${ }^{70}$ Kenneth Schmitz, "Metaphysics: Radical, Comprehensive, Determinate Discourse," in The Review of Metaphysics 39, no. 4 (1986): 693. 
Thus, in speaking about the (1) Christian disclosure of the human person and his or her infinite capability to love, (2) mirroring the relational persons of the Trinity, which (3) stands not as One solitary and transcendent reality, but as relational (that is to say, pluralized), we can now go back to Heidegger-Schürmann and see whether Schmitz was justified in speaking of the special contribution of Christian discourse to the closure of the metaphysical field.

\section{The Challenge of Christian Trinitarian Thought}

We are now in a position to articulate the specific response of Christian Trinitarian thought to the challenge of Schürmann. It is in love that we are able to find the fullest account of the Christian disclosure at the end of metaphysics: (1) love gives us a clue to the structure of reality as originating from what Schmitz would call "a caring presence,"71 (2) it also reveals an account of human flourishing that analogously mirrors that of the Christian disclosure of the Trinity. Let us go over these two points.

Ratzinger puts the first point, beautifully: "To him who believes in God as tri-une, the highest unity is not the unity of inflexible monotony. The model of unity or oneness toward which one should strive is consequently not the indivisibility of the atom, the smallest unity, which cannot be divided up any further; the authentic acme of unity is the unity created by love. The multi-unity that grows in love is a more radical, truer unity than the unity of the 'atom."'72

We recall that for Schürmann, the structure of reality is wholly determined by the epochal constellations of Being's unveiling, insofar as these structures are determinate and provisional according to their own proper epochal limits. At the heart of his structure is an overriding principle that allows not only for the intelligibility of everything that relates

\footnotetext{
${ }^{71}$ Schmitz, "From Anarchy to Principles."

72 Josef Ratzinger, Introduction to Christianity, trans. J. R. Foster and Michael Miller (San Francisco: Burns and Oates, Ltd., 1969), 179.
} 
itself in the economy, but also and more importantly for the principle of inception that allows for things to be in that particular economy in the first place. The pros ben schema serves as the superstructure in which all thinking and doing are anchored on an overriding metaphysical principle. To this the Christian disclosure offers a God that is not self-enclosed, but in fact thrives in its inner differentiation: "if the principle is one, yet not hostile to inner distinction (as, theologically and in respect to the Trinity, we speak of the distinct persons and their different processions and missions), then the charge of closure must be reopened for discussion." 73 By virtue of the subsistent relations of the three persons of God, we are offered a principal point of reference that is itself dynamic, and thus beyond the static conceptions of metaphysical foundations such as ousia, cogito, and the transcendental ego. The tri-Personality of God is not the metaphysical First that Schürmann seems to happily apply to all metaphysical systems; it is a God that is first of all in act. We can thus understand the dictum agere sequitur esse as that which considers action not as an accident of Being, but rather and more importantly, as constitutive of the beingness of Beingaction. In fact, Saint Thomas speaks of it explicitly: "Being properly signifies: something-existing-in-act." ${ }^{\text {T4 }}$

We thus disagree Schürmann when he says that "practical reason [ever since Socrates] receives its architecture from pure reason; and that theoria, because it is what is most noble within our reach, prescribes the routes to praxis." 75 We can grant his conception of the relations that dictate practice, it must be said that for Saint Thomas, the rational foundation for practice is not a domineering static metaphysical principle: it is a tri-Personal God that is pure act. It is therefore not a subsumption of act under thinking, as is the case with Schürmann's epochal economies: it is a participation of action in the relationality of a tri-Personal God.

\footnotetext{
${ }^{73}$ Schmitz, "From Anarchy to Principles."

${ }^{74}$ Saint Thomas Aquinas, An Introduction to the Metaphysics of St. Thomas Aquinas, ed. and trans. James F. Anderson (Washington, DC: Regnery Publishing, Inc., 1953), 20.

${ }^{75}$ Schürmann, "What Must I Do," 56.
} 
In articulating a tri-Personal God in act, Saint Thomas positions himself outside the determinations of onto-theological metaphysics, because he treats God as pure act, such that Being and action are inseparable. The critical hinge here is that at the root of this conception of Being is the revelation that God Himself is One, and His is an inner distinction of persons as pure relations: God's Oneness is many. This gives us the most forceful response against Schürmann: the tri-Personality of God is not a rational foundation established by human beings, as with the epochal metaphysical foundations; it is, in the final analysis revealed. We can thus say that Saint Thomas provides us an account of God that is not reducible to a hard unity, but in fact lives and acts according to its persons and relations. Central to this is the discovery of the human person along with all beings that participate in the plenitude of God as a communion of subsistent relations: "It is not a 'God-nature' that acts, but a tri-personal God whose nature is one." " We thus have, in this Christian disclosure, the revelation of the structure of reality as dynamic because it is dyadic. ${ }^{77}$

Which brings us to the second point: the Christian disclosure points out that what was revealed was more than any theory about the "good life," nor was it an overarching "secret knowledge" about reality: at the heart of the revelation was a real and embodied truth-the person. Ratzinger again puts it beautifully: "Just when we seem to have reached the extreme limit of theory, the extreme of practicality comes into view: talking about God discloses what man is; the most paradoxical approach is at the same time the most illuminating and helpful one." 78

Though it is true that Schürmann rightly speaks of the gradual withering away of the anthropocentric vision of man, he was doing so in the context of the modern and isolated $\operatorname{man}^{79}$ What we have with the Thomistic exposition is the person in its most dynamic and self-

\footnotetext{
${ }^{76}$ De Lubac, Christian Faith, 131.

${ }^{77}$ Clarke, "Substance-in-Relation," 113.

${ }^{78}$ Ratzinger, Introduction to Christianity, 190.

${ }^{79}$ Clarke points out that it is in modernity that the notion of substance becomes an isolated and self-regulating metaphysical category. See Clarke, "Substance-in-Relation," 113.
} 
communicating sense that is paradigmatically expressed in God. The special consideration that has to be explicitly stated here is that "person" in his or her constitution as person-in-relation is itself disclosed in Christian historicity. But philosophy can appropriate this theological insight in light of its own historicity. There is thus a sharp distinction between buman being and person: as man is but a member of the eternal play of concealment/unconcealment, person is a disclosure of its constitution as relatedness, which traces itself to the disclosure that God is this tripersonal Being by virtue of its subsistent relations. What this means philosophically (that is, analogically) is: the human person is intrinsically related to other beings by virtue of its substantiality, i.e., uniqueness. The person is individuated, but in his or her individuation stands his active presencing and communication. He is both individual and relational. Schürmann may have had a too-narrow conception of man when he inaugurated the "threefold break with humanism," especially since he considered "man" from the purview of modern thought, which viewed man as individuated and isolated. The Christian disclosure offers a vision of man as person created in the image and likeness (i.e., analogously) of God. ${ }^{80}$

We thus share in Bernard Dauenhauer's reluctance in admitting to Schürmann's account of the theory of relations: it is not only through the overriding principle of the metaphysical First that we are related; it is also with other beings - most especially people-with whom we construct meaningful lives. ${ }^{81}$ It is also at this point that we recall our earlier discussion on person and reiterate once more: to enter into relations is to enter into love; 82 to live in the relatedness of things is the fruition of love, and more so the fruition of oneself not as lover, but in fact, as loved. Loved by whom? This is the most basic article of faith that is communicated to us: we are loved by God.

\footnotetext{
${ }^{80}$ Clarke, "Substance-in-Relations," 118.

${ }^{81}$ Bernard Dauenhauer, "Does Anarchy Make Political Sense? A Response to Schürmann," Human Studies 1, no. 4 (1978): 373.

${ }^{82} \mathrm{I}$ am not going to enter into the philosophical discussion on charity, since it merits a much longer discussion.
} 
Bearing these shifts in our evaluation of Schürmann, we can finally answer his question: What must I do at the end of metaphysics?-We say: To (still) love. This is the challenge of the Christian disclosure: to bear within oneself the capability to love others, for only in loving others can we truly enter into relations with one another. This capability does not at all come from oneself; man is not the final wellspring of action. The capability to love comes from that which loved First. It is in relating in a way analogous to God's subsistent-relation that we are able to enact this love revealed to us through the dynamism of the Trinity. Thus we enter more deeply into the question What must we do? - for we are not just inquiring about the link between thought and action; we are in fact inquiring about God.

It is at this point that the Christian disclosure indeed opens up new patterns of thought and action: it is through the self-communication of the Trinity that we see (1) that our principal ground for all being is not a form of hard oneness, but a community of Three; (2) that community is itself composed of persons in relation; and finally (3) that such persons only enter into relations in charity, that is, acting according to one's ontological structure of being substance-in-relations. With Schürmann in mind, therefore, we say: the Christian disclosure calls us, over and beyond calculative thinking, in fact, to still live kata physin - to live by entering into mutual relations to one another. But against Schürmann we say: we do not enter into relations because the old relational structure has come and gone-we enter into relations because it is revealed that we were made in such a way that to live is to relate to others in love, and that God-the principal ground of all-is within Himself pluralized and relational. Thus, we can say that Schürmann and Heidegger aid us in removing the clutter left by onto-theological metaphysics that have crept into Christian thought, but that over and against Schürmann and Heidegger, we uncover a more primordial truth than that of Ereignis - a loving God that became man.

It is in this intimate encounter with the tri-personal God that we "enter into mutual relations" with one another, not because old metaphysical regimes have now been dismantled, but because it is now clear, at the end 
of metaphysics, that it is still possible to talk about grounding oneself, because the Ground is charitably plural. Such a ground cannot but be reflected in human thinking and doing, for indeed if we are the image and likeness of God, we cannot but love. So what must we do at the end of metaphysics? - To (still) love. We can take our cue from Saint Irenaeus in understanding our contemporary task at the twilight of traditional metaphysical thinking: Gloria enim Dei vivens homo, vita autem hominis est visio $D e i^{83}$

\section{Bibliography}

Aquinas, Saint Thomas. An Introduction to the Metaphysics of St. Thomas Aquinas. Edited and translated by James F. Anderson. Washington, DC: Regnery Publishing, Inc., 1953.

- Quaestiones Disputatae de Potentia Dei. Translated by the English Dominican Fathers. Westminster, Maryland: the Newman Press, 1952.

Summa Contra Gentiles. Translated by Anton C. Pegis. Indiana: University of Notre Dame Press, 1975.

Summa Theologiae. Blackfriars English Translation. 60 vols. London and New York, 1964-1976.

Clarke, S.J., W. Norris. The One and the Many: a Contemporary Thomistic Metaphysics. Indiana: University of Notre Dame Press, 2001.

."The Self as Source of Meaning in Metaphysics." The Review of Metaphysics 21, no. 4 (1968): 597-614.

${ }^{83}$ Loosely translated as, "The glory of God is a living man, and the life of man is the vision of God." Cf. Saint Irenaeus of Lyons, Adversus Haereses IV.20, accessed August 13, 2013, http://www.newadvent.org/fathers/0103420.htm. 
. "To Be is to Be Substance-in-Relation." In Explorations in Metaphysics, 102-22. Notre Dame: University of Notre Dame Press, 1994.

Craig, William Lane, and J. P. Moreland. "The Trinity." In Oxford Readings in Philosophical Theology, vol. 1, Trinity, Incarnation, Atonement, edited by Michael Rea, 21-43. Oxford: Oxford University Press, 2009.

Cross, Richard. "Two Models of the Trinity?” In Oxford Readings in Philosopbical Theology, vol. 1,: Trinity, Incarnation, Atonement, edited by Michael Rea, 107-26. Oxford: Oxford University Press, 2009.

Dauenhauer, Bernard P. "Does Anarchy Make Political Sense? A Response to Schürmann." Human Studies 1, no. 4 (1978): 369-75.

De Lubac, Henri, S.J. The Christian Faith: An Essay on the Structure of the Apostles' Creed. Translated by Richard Arnandez, F.S.C. San Francisco: Ignatius Press, 1986.

Emery, Gilles, O.P. The Trinitarian Theology of St. Thomas Aquinas. Translated by Francesca Aran Murphy. Oxford: Oxford University Press, 2007.

Heidegger, Martin. "The End of Philosophy and the Task of Thinking." In On Time and Being, translated by Joan Stambaugh, 55-73. New York: Harper and Row, Inc., 1972.

. "The Onto-Theo-Logical Constitution of Metaphysics." In Identity and Difference, translated by Joan Stambaugh, 42-74. Chicago: Chicago University Press, 2002

Irenaeus of Lyons, Saint. Adversus Haereses. Accessed August 13, 2013. ttp://www.newadvent.org/fathers/0103420.htm.

Marion, Jean-Luc. "Christian Philosophy: Hermeneutic or Heuristic?" In The Question of Christian Philosophy Today, edited by Francis J. Ambrosio, 247-64. New York: Fordham University Press, 1999.

. God Without Being: Hors-Texte. 2nd ed. Translated by Thomas Carlson. Chicago: Chicago University Press, 2012.

—. "The End of the End of Metaphysics." Epochē 2 (1994): 1-22.

. "The Possible and Revelation." In The Visible and the Revealed, translated by Christina M. Gewandtner, 1-18. New York: Fordham University Press, 2008.

O' Collins, Gerald, S.J. The Tripersonal God: Understanding and Interpreting the Trinity. New Jersey: Paulist Press, 1999.

Peperzak, Adriaan. "Religion After Onto-Theology?” In Religion After Metaphysics, edited by Mark A. Wrathall, 104-22. Cambridge: Cambridge University Press, 2003.

Ratzinger, Josef. Introduction to Christianity. Translated by J. R. Foster and Michael Miller. San Francisco: Burns and Oates, Ltd., 1969. 
Schmitz, Kenneth L. "From Anarchy to Principles: Deconstruction and the Resources of Christian Philosophy." Council of Research and Values in Philosophy. Accessed March 3, 2013. http://www.crvp.org/book/Series04/IVA-1 /chapter_xvi.htm.

" "Metaphysics: Radical, Comprehensive, Determinate Discourse." The Review of Metaphysics 39, no. 4 (1986): 675-94.

Schürmann, Reiner. Heidegger on Being and Acting: From Principles to Anarchy. Translated by Christine Marie-Gros. Bloomington: Indiana University Press, 1987.

"'What Must I Do?" at the End of Metaphysics: Ethical Norms and the Hypothesis of a Historical Closure." In Phenomenology in a Pluralistic Context, edited by William L. McBride and Calvin O. Schrag, 49-64. Albany: State University of New York Press, 1983.

Wrathall, Mark A. "Between the Earth and Sky: Heidegger on Life After the Death of God." In Religion After Metaphysics, edited by Mark A. Wrathall, 69-87. Cambridge: Cambridge University Press, 2003. 